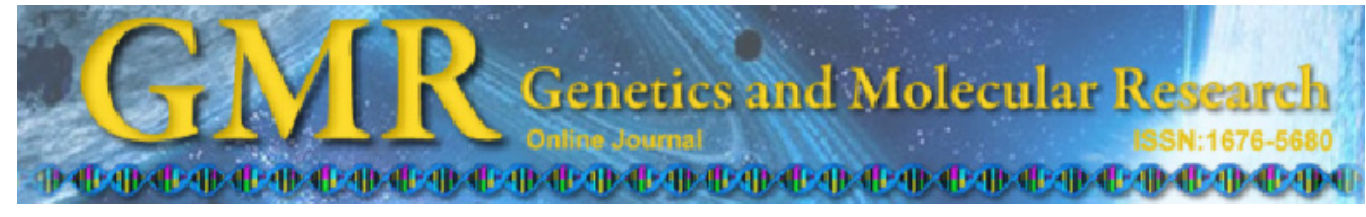

\title{
Identification of single nucleotide polymorphisms in the CCNA2 gene and its association with wool density in Rex rabbits
}

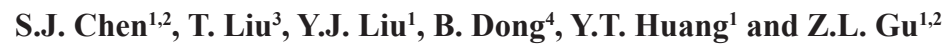 \\ ${ }^{1}$ Mountain Area Research Institute, Agricultural University of Hebei, \\ Baoding, Hebei, P.R. China \\ ${ }^{2}$ College of Animal Science and Technology, \\ Agricultural University of Hebei, Baoding, Hebei, P.R. China \\ ${ }^{3}$ Ringpu Biological Pharmaceutical Co., Ltd., Baoding, Hebei, P.R. China \\ ${ }^{4}$ Division of Scientific Research, Agricultural University of Hebei, \\ Baoding, Hebei, P.R. China \\ Corresponding author: Z.L. Gu \\ E-mail: shyxq@hebau.edu.cn
}

Genet. Mol. Res. 10 (4): 3365-3370 (2011)

Received March 29, 2011

Accepted September 5, 2011

Published November 4, 2011

DOI http://dx.doi.org/10.4238/2011.November.4.1

\begin{abstract}
The Rex rabbit is a typical fur breed. Wool density, hair length, wool fineness, and hide area are the main indices of fur quality. We previously found that the CCNA2 gene plays an important role in hair follicle initiation and development, and it is involved in the distinctive wool density of the Rex rabbit. It is an important candidate gene for wool density selection through markerassisted selection. We conducted an association study to identify single nucleotide polymorphisms (SNPs) within the CCNA2 gene and their ligands associated with wool density. Using PCR-RFLP technology, we discovered two SNPs $(129 \mathrm{G}>\mathrm{A}$ and $1140 \mathrm{G}>\mathrm{C})$ of the CCNA2 gene. Allele frequencies of these two SNPs were investigated and evaluated by the $\chi^{2}$ test in 100 Rex rabbits. The two SNPs were both in Hardy-Weinberg equilibrium. We also looked
\end{abstract}


for a potential association of these SNPs with fur traits in 100 Rex rabbits. Rex rabbits with the GG genotype had significantly higher wool density $(\mathrm{P}<0.01)$ than those with other genotypes; the other three fur traits did not differ significantly among the genotypes. In conclusion, the two SNPs of the CCNA2 gene affect wool density in the Rex rabbit.

Key words: Rex rabbit; CCNA2 gene; SNPs; Fur; Wool density

\section{INTRODUCTION}

As the Rex rabbit is commonly used for fur, wool density is one of the most important traits to evaluate the quality of its fur. Choosing candidate genes to detect molecular markers linked to wool density by polymorphism analysis, may be helpful for the early selection-breeding of Rex rabbit. In our earlier studies, gene expression patterns in different wool densities of Rex rabbit were identified by cDNA microarray. A total of 2657 differentially expressed genes were identified. Among them, 1103 genes were functionally known genes, and 687 genes were up-regulated and 419 down-regulated. The Gene Ontology (GO) analysis indicated that these altered genes were associated with metabolism, signal transduction, cell cycle, cell adhesion, cell proliferation, cell division, apoptosis and other processes. Some important differentially expressed genes in different wool densities of Rex rabbit were identified, including MMP2, TGF- $\beta 1$, TGF- $\beta 2$, IGF-1, ITGB1, RPS6KB1, BMP2, ActR $\alpha$ B, CDK2, and CCNA2. The abnormal expression of these genes may play an important role in the initiation and development of hair follicles, finally leading to the distinction in wool density of Rex rabbit (Chen et al., 2011).

The cell cycle, or cell-division cycle, is the series of events that takes place in a cell leading to its division and duplication (replication). The cell-division cycle is a vital process by which a single-celled fertilized egg develops into a mature organism, as well as the process by which hair, skin, blood cells, and some internal organs are renewed (Girard et al., 1991). The cyclin A2 (CCNA2) protein encoded by CCNA2 gene belongs to the highly conserved cyclin family, whose members are characterized by a dramatic periodicity in protein abundance through the cell cycle (Wang et al., 1990). Cyclins function as regulators of CDK kinases. Different cyclins exhibit distinct expression and degradation patterns which contribute to the temporal coordination of each mitotic event (Furuno et al., 1999; Gong and Ferrell, 2010). In contrast to cyclin A1, which is present only in germ cells, cyclin A2 is expressed in all tissues tested. Cyclin A2 binds and activates CDC2 or CDK2 kinases, and thus promotes both cell cycle G1/S and G2/M transitions (Cordon-Cardo, 1995; Jeffrey et al., 1995; Michalides, 1999).

To our knowledge, there is no reported information so far on the polymorphism of the Rex rabbit CCNA2 gene and on the wool density selection through marker-assisted selection. On the basis of the biological function of the CCNA2 gene and previous results of the above-mentioned experiment, it is hypothesized that the CCNA2 gene could play an important role in the wool density trait in Rex rabbits. Therefore, the objective of this study was to identify SNPs of the Rex rabbit CCNA2 gene and to determine the association of these SNPs with wool density in Rex rabbit. 


\section{MATERIAL AND METHODS}

\section{Animals and RNA samples}

This experiment was carried out at a Rex rabbit farm in Baoding, China. The rabbits were housed individually in closed buildings with a natural ventilation and had free access to water. Data on fur traits: body weight, wool density (Gu et al., 1999), wool fineness and hair length were measured at 14 weeks of age. All of them were born in February 2010. The blood samples were collected from 100 Rex rabbits. Catrimox-14 ${ }^{\circledR}$ Solution (Takara, China) was used as a cell lysis agent to treat blood, which was then incubated for $15 \mathrm{~min}$ at room temperature and stored at $-80^{\circ} \mathrm{C}$.

Total RNA from blood samples was isolated by the guanidinium isothiocyanate method. Concentration and RNA quality were assessed via spectrophotometry and denaturing agarose gel electrophoresis. All isolated total RNA had a 260/280 nm ratio of more than 1.8. RNA integrity was verified by inspection of the $28 \mathrm{~S}$ and $18 \mathrm{~S}$ rRNA bands on denaturing formaldehyde agarose gels $(1.2 \%)$ and determined by densitometry. Then the RNA was used as a template for cDNA synthesis for $1 \mathrm{~h}$ at $42^{\circ} \mathrm{C}$.

\section{Amplification and sequencing of the CCNA2 gene}

According to the sequence of the Oryctolagus cuniculus CCNA2 gene (GenBank accession No. XM_002717232), two pairs of primer were designed to amplify the CCNA2 gene (CCNA2 1) forward: 5'-TAGAGGACCAGGAGAACATC-3', reverse: 5'-CCAGTC CACGAGGATAGC-3'; CCNA2(2) forward: 5'-ATCCTCGTGGACTGGTTAG-3', reverse: 5'-CTCTTATTGATTGTTGTGC-3'). PCR was performed in a $20 \mu \mathrm{L}$ reaction mixture containing $50 \mathrm{ng}$ DNA, $10 \mathrm{pM}$ of each primer, $0.20 \mathrm{mM}$ dNTP, $2.5 \mathrm{mM} \mathrm{MgCl} 2$ and $0.5 \mathrm{U}$ Ex-Taq DNA polymerase (TaKaRa, China). The cycling protocol: $94^{\circ} \mathrm{C}$ for $5 \mathrm{~min}(1 \mathrm{cycle})$, and $94^{\circ} \mathrm{C}$ for $45 \mathrm{~s}, 50^{\circ} \mathrm{C}$ (CCNA2 1) or $48^{\circ} \mathrm{C}$ (CCNA2(2) for $45 \mathrm{~s}, 72^{\circ} \mathrm{C}$ for $1 \mathrm{~min}\left(34\right.$ cycles), and $72^{\circ} \mathrm{C}$ for $10 \mathrm{~min}$ ( 1 cycle). The PCR products were detected by $1.2 \%$ agarose gel electrophoresis and purified with the Agarose Gel DNA Purification Kit (TaKaRa, China). Then the PCR products from 40 Rex rabbits were selected for sequencing in both directions in an ABI PRIZM 377 DNA sequencer (Perkin-Elmer, USA). Sequences were analyzed using DNAStar software in order to find the SNP and screen the enzyme site.

\section{Genotyping of the CCNA2 allele by PCR-RFLP}

The implementation of a PCR-RFLP protocol to genotype animals from 100 Rex rabbits was carried out for the $129 \mathrm{G}>\mathrm{A}$ and $1140 \mathrm{G}>\mathrm{C}$ SNP. The PCR products were digested with the restriction enzyme $S c a$ I and AfIII (NEB, England), respectively. The restriction fragments were detected by electrophoresis on $1.2 \%$ agarose gels.

\section{Statistical analysis}

Allele and genotype frequencies and their accordance with the Hardy-Weinberg law were determined by PopGen software version 3.2 (http://www.ualberta.ca/nfyeh/index.htm). 
The association between the polymorphism of the CCNA2 gene and wool density was analyzed with the GLM procedure of the SPSS software version 13.0 (SPSS, Chicago, USA).

\section{RESULTS AND DISCUSSION}

\section{The results of polymorphisms}

In this paper, the polymorphisms of CCNA2 gene were detected by DNA sequencing and PCR-RFLP methods. After the PCR products of the CCNA2 gene were amplified and sequenced, we found two mutations $(129 \mathrm{G}>\mathrm{A}$ and $1140 \mathrm{G}>\mathrm{C})$ were located in the CCNA2 gene in Rex rabbit. The sequencing tracing are shown in Figure 1. The 129G $>$ A SNP is a synonymous mutation of alanine, which creates the $S c a$ I restriction site (AGT^ACT). The $1140 \mathrm{G}>\mathrm{C}$ SNP is a missense mutation from lysine to asparagine, which destroys the AfIII restriction site $\left(\mathrm{C}^{\wedge} \mathrm{TTAA} \underline{\mathrm{G}}\right)$. The sequences were deposited in the GenBank database (accession Nos. JF746894 and JF746895).
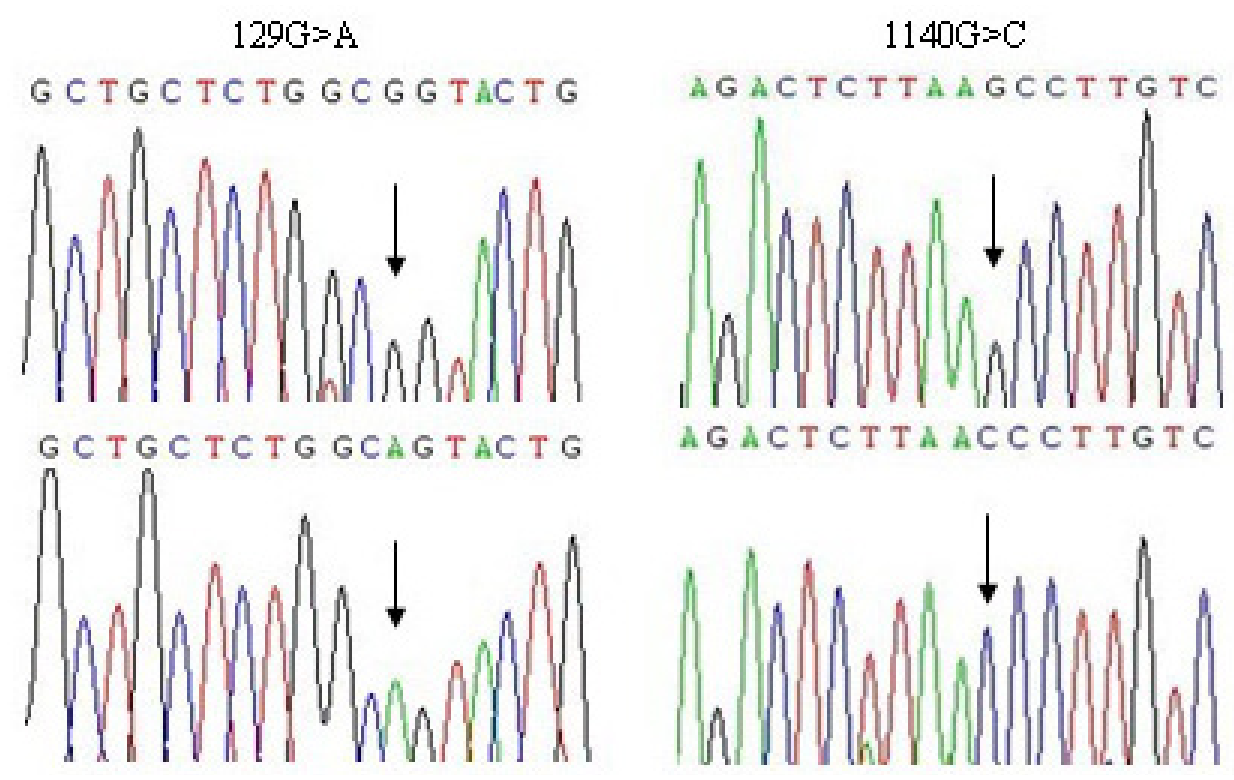

Figure 1. DNA sequencing tracing of the CCNA2 gene.

Subsequently, we analyzed the localization of migration bands of the restriction fragments and found three genotypes of " $129 \mathrm{G}>A$ " and " $1140 \mathrm{G}>C$ ". Figure $2 \mathrm{~A}(129 \mathrm{G}>\mathrm{A})$ shows the following electrophoretic patterns: genotype GG represents the occurrence of one band of $572 \mathrm{bp}$; genotype GA represents three restriction fragment bands of 572, 500 and $72 \mathrm{bp}$, and genotype AA represents two restriction fragment bands of 500 and $72 \mathrm{bp}$. Figure $2 \mathrm{~B}(1140 \mathrm{G}>\mathrm{C})$ shows the following electrophoretic patterns: genotype GG represents two restriction fragment bands of 522 and $73 \mathrm{bp}$; genotype GC represents three restriction fragment bands of 595, 522, and $73 \mathrm{bp}$, and genotype CC represents the occurrence of one band of $595 \mathrm{bp}$. 
GA $\quad \mathrm{M}$ GA GG GG AA

A

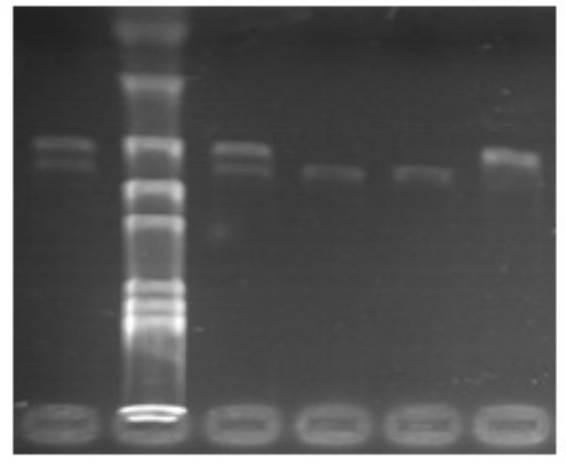

M $\quad$ GG $\quad$ GG $\quad$ CC $\quad \mathrm{CC} \quad \mathrm{GC}$

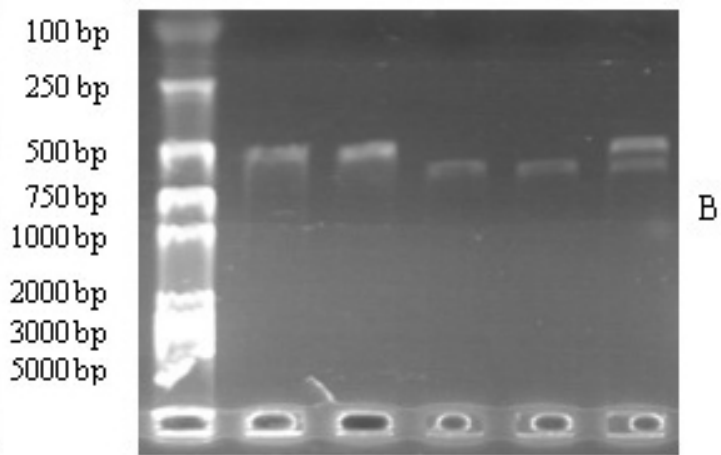

Figure 2. PCR-RFLP results. A. Agarose gel electrophoresis of ScaI PCR-RFLP. GG genotype shows one fragments (572 bp), GA genotype shows three fragments $(572,500$ and $72 \mathrm{bp}$ ) and AA genotype shows two fragments (500 and $72 \mathrm{bp}$ ). B. Agarose gel electrophoresis of AfIII PCR-RFLP. CC genotype shows one fragments (595 bp), GC genotype shows three fragments $(595,522$ and $73 \mathrm{bp}$ ) and GG genotype shows two fragments (522 and $73 \mathrm{bp})$. The 72 and $73 \mathrm{bp}$ fragments never appear on the images of gels.

The frequencies of GG, GA and AA genotypes of $129 \mathrm{G}>\mathrm{A}$ were 39,34 and $27 \%$, and the frequencies of alleles $\mathrm{G}$ and $\mathrm{A}$ were: 0.56 and 0.44 , respectively. The frequencies of GG, $\mathrm{GC}$ and $\mathrm{CC}$ genotypes of $1140 \mathrm{G}>\mathrm{C}$ were 35,37 and $28 \%$, and the frequencies of alleles $\mathrm{G}$ and $\mathrm{C}$ were: 0.535 and 0.465 , respectively. The $\chi^{2}$ test showed no significant difference at the two mutation sites $(\mathrm{P}>0.05)$. The two polymorphism sites were all in Hardy-Weinberg equilibrium.

\section{Association between Rex rabbit fur traits and CCNA2 gene polymorphism}

The association between the CCNA2 polymorphism and fur traits (body weight, wool density, wool fineness and hair length) were analyzed in Rex rabbit $(\mathrm{N}=100)$ (Tables 1 and 2). At the $129 \mathrm{G}>\mathrm{A}$ SNP marker, there are significant effects on the wool density $(\mathrm{P}<0.01)$, where the wool density of the GG genotype is significantly higher than that of GA and AA genotypes, and the wool density of the GA genotype is significantly higher than that of genotype AA (P< $0.01)$. The other three traits have no significant difference among the 3 genotypes GG, GA and AA $(\mathrm{P}>0.05)$. The same tendency is shown in the $1140 \mathrm{G}>\mathrm{C}$ SNP marker, the wool density of the GG genotype is significantly higher than those of GC and CC genotypes, and the wool density of the GC genotype is significantly higher than that of genotype $\mathrm{CC}(\mathrm{P}<0.01)$. The other three traits have no significant difference among the 3 genotypes GG, GC and $\mathrm{CC}(\mathrm{P}>0.05)$.

Wool density, hair length, wool fineness and area of hide are the main indices of fur quality. In general, there is a positive correlation between body weight and area of hide, the higher the body weight, the greater the area of hide. So we measured the 100 Rex rabbits for body weight, wool density, wool fineness and hair length, and determined the association of SNPs in the CCNA2 gene with wool density in Rex rabbit. The results indicated that, at the $129 \mathrm{G}>\mathrm{A}$ and $1140 \mathrm{G}>\mathrm{C}$ SNP marker, the GG genotype has high wool density, and has no adverse effect on the other fur indices (hair length, wool fineness and body weight). Therefore, the GG genotypes of "129G $>A$ " and "1140G $>C$ " were the most favorable at the CCNA2 gene for wool density trait in Rex rabbit. 
Table 1. Association of $129 \mathrm{G}>\mathrm{A}$ SNP of the CCNA2 gene with fur traits in Rex rabbit.

\begin{tabular}{lccccc}
\hline Genotype & Number & Body weight 3 months $(\mathrm{kg})$ & Wool density $\left(\right.$ pieces per $\left.\mathrm{cm}^{2}\right)$ & Wool fineness $(\mu \mathrm{m})$ & Hair length $(\mathrm{cm})$ \\
\hline GG & 39 & $2.49 \pm 0.28$ & $18334 \pm 1247^{\mathrm{A}}$ & $16.72 \pm 1.92$ & $2.31 \pm 0.13$ \\
GA & 34 & $2.52 \pm 0.34$ & $15625 \pm 2316^{\mathrm{B}}$ & $16.62 \pm 1.61$ & $2.32 \pm 0.15$ \\
AA & 27 & $2.46 \pm 0.32$ & $12447 \pm 1465^{\mathrm{C}}$ & $16.64 \pm 1.88$ & $2.29 \pm 0.12$ \\
\hline
\end{tabular}

Means with different superscript letters are significantly different $(\mathrm{P}<0.01)$.

Table 2. Association of 1140G $>$ C SNP of the CCNA2 gene with fur traits in Rex rabbit.
\begin{tabular}{lccccc}
\hline Genotype & Number & Body weight 3 months $(\mathrm{kg})$ & Wool density (pieces per $\left.\mathrm{cm}^{2}\right)$ & Wool fineness $(\mu \mathrm{m})$ & Hair length $(\mathrm{cm})$ \\
\hline GG & 35 & $2.51 \pm 0.31$ & $18273 \pm 1346^{\mathrm{A}}$ & $16.68 \pm 1.63$ & $2.32 \pm 0.14$ \\
GC & 37 & $2.49 \pm 0.32$ & $15318 \pm 1873^{\mathrm{B}}$ & $16.71 \pm 1.82$ & $2.30 \pm 0.12$ \\
CC & 28 & $2.47 \pm 0.28$ & $12269 \pm 2015^{\mathrm{C}}$ & $16.63 \pm 1.57$ & $2.28 \pm 0.11$ \\
\hline
\end{tabular}

Means with different superscript letters are significantly different $(\mathrm{P}<0.01)$.

In conclusion, we identified two SNPs in the CCNA2 gene and determined the association of these SNPs with wool density in Rex rabbit. Our results provide evidence that the CCNA2 gene has potential effects on wool density in Rex rabbit. Therefore, further study will be necessary before using these SNPs for marker-assisted selection in larger populations.

\section{ACKNOWLEDGMENTS}

Research supported by the Modern Agriculture (rabbit) Industrial Science and Technology System Projects from the Ministry of Agriculture of P.R. China (\#nycyti-44) and Science and Technology Supporting Projects from Hebei Province of P.R. China (\#06220402D-4).

\section{REFERENCES}

Chen SJ, Liu T, Liu YJ and Dong B (2011). Gene expression patterns in different wool densities of Rex rabbit using cDNA microarray. Agr. Sci. China 10: 101-105.

Cordon-Cardo C (1995). Mutations of cell cycle regulators. Biological and clinical implications for human neoplasia. Am. J. Pathol. 147: 545-560.

Furuno N, den Elzen N and Pines J (1999). Human cyclin A is required for mitosis until mid prophase. J. Cell Biol. 147: 295-306.

Girard F, Strausfeld U, Fernandez A and Lamb NJ (1991). Cyclin A is required for the onset of DNA replication in mammalian fibroblasts. Cell 67: 1169-1179.

Gong D and Ferrell JE Jr (2010). The roles of cyclin A2, B1, and B2 in early and late mitotic events. Mol. Biol. Cell 21: 3149-3161.

Gu ZL, Gu SG, Ren WS and Huang RL (1999). Study on density of rex rabbit. Chin. J. Rabbit Farming 4: 18-21.

Jeffrey PD, Russo AA, Polyak K, Gibbs E, et al. (1995). Mechanism of CDK activation revealed by the structure of a cyclinA-CDK2 complex. Nature 376: 313-320.

Michalides RJ (1999). Cell cycle regulators: mechanisms and their role in aetiology, prognosis, and treatment of cancer. J. Clin. Pathol. 52: 555-568.

Wang J, Chenivesse X, Henglein B and Bréchot C (1990). Hepatis B virus integration in a cyclin A gene in a hepatocellular carcinoma. Nature 343: 555-557. 